\title{
TILLAGE TESTS: II, THE BENEFICIAL EFFECT OF SUBSOIL FERTILIZATION ON SUGARCANE YIELDS
}

\author{
M. B. Martinez and M. A. Lugo-López ${ }^{1}$
}

\section{INTRODUCTION}

The influence of deep tillage in loosening tight subsoil layers is generally considered desirable because physical conditions suitable for root development, such as rapid riddance of excess water and adequate aeration, are thus promoted. The available literature concerning this subject embodies rather wide discrepancies concerning the effect of deep tillage upon crop yields, but it is generally accepted that with improved drainage and aeration, crop plants develop more extensire and deeper root systems. Consequently, plant roots can exploit a larger volume of soil in their search for moisture and nutrients. Soils with fertile or moderately fertile subsoil layers may release mineral nutrients helpful for crop development. However, subsoils are generally infertile and plant nutrients must be supplied at lower depths if a favorable fertility level is to be maintained for plant growth.

Subsoiling has been a regular practice in some Puerto Rican cane fields, particularly in the southern irrigated plantations; but there is no experimental evidence to indicate its beneficial effect on soil tilth or crop yields. Subsoil fertilization and liming are virtually unused by our sugarcane growers. A regular practice on our plantations is to apply the fertilizer to the soil next to the base of the sugarcane seedling in plant cane, and to the clump in ratoon cane.

This paper reports the effects of subsoiling and subsoil fertilization on sugarcane yields. The results may help to clarify some of the concepts involved and to correct the apparent discrepancies found in the literature.

\section{REVIEW OF LITERATURE}

Smith, et al. found that subsurface tillage produced more beneficial effects on soil condition when the subsoil was shattered while semidry $(22)^{2}$, so that the large soil masses were effectively broken up and more favorable physical characteristics were obtained. The breaking of plowpans and loosening of tight subsoil layers have proven beneficial to crops in some of the older agricultural areas $(2,5,8,12,15,18,19,20)$. However,

${ }^{1}$ Research Assistant in Agricultural Engineering and Associate Soil Scientist, respectively, Agricultural Experiment Station, University of Puerto Rico, Río Piedras, P. R.

2 Numbers in parentheses refer to Literature Cited, pp. 42-3. 
in some cases no effects on yield were reported from deep tillage in various areas of the Great Plains and Middle West in continental United States $(11,13,23 ; 3,21)$. Martínez and Lugo-López observed highly significant differences in the minimum infiltration capacity of heavy soils where subsoils were broken, as compared with check plots tilled as is customary on the plow layer only (10).

Wolters observed the beneficial effects of hook subsoiling in Hawaii on older ratoon crops (25) and Borden held that heavy stooling and shoot growth occurred primarily because the fertilizer got well down into the lower layers of the soil (1). In the same article, Borden reported data from Mitscherlich's pot tests using Sudan grass and comparing differences in yields between surface soils and subsoils at various fertility levels. $\mathrm{He}$ concluded that good aeration by itself was insufficient to make subsoils produce satisfactory yields. But, when the fertility level of the subsoil was raised to that of the surface soil, the yields obtained from each were not significantly different. Woodruff and Smith obtained very significant results in their experiments with sweetclover in one Missouri soil when subsoil liming accompanied the tillage operation; a more extensive and deeper root system was developed (26).

In view of the above it is important to emphasize the fact that, since there are soils where roots fail to develop well below the surface layer because of restricted aeration, and since there are also soils where roots fail to develop even under favorable aeration and internal drainage, the lack of available nutrients in the subsoil is probably a limiting factor for root extension and crop growth and production. In a previous paper a more detailed discussion of the theoretical considerations involved was presented (9).

\section{EXPERIMENTAL PROCEDURE}

About 10 acres of land were selected at Colonia Preston, a large sugar estate owned by the Eastern Sugar Associates in east-central Puerto Rico. Various pits were dug at different parts of the field to study the morphological characteristics of the soil. In addition, soil cores for laboratory analyses were taken with a Kelley (Utah) soil-sampling machine (6).

The $\mathrm{pH}$ was determined electrometrically by using a Macbeth $\mathrm{pH}$ meter with a glass electrode. Total nitrogen was determined by the standard Kjeldahl method and the organic matter by the simple colorimetric Schollenberger technique. Total exchange capacity and exchangeable bases were determined as suggested by Peech (14).

The soil, previously mapped as Vía silty clay, appeared upon field examination more nearly to approach a Caguas silt loam (17). The plow layer was a light grayish-brown silt loam with a weak fine granular structure and contained many small dark concretions with a mean diameter of 
one-eighth of an inch. It was underlain by a 9-inch, highly mottled transition layer with a well-developed fragmental blocky structure. Beyond the 16-inch depth the soil was highly mottled with gray shades predominating; and was mostly a tight plastic clay which looked like putty and had a fragmental-blocky structure, coarser than the layer above.

A triple-lattice design was used for the experimental lay-out (4). The plots were rather large, 200 feet long by 20 feet wide, to provide ample space for the heavy machinery used. Land preparation began on October 11, 1950, when the sod was disked twice, and was followed by plowing and harrowing three times to a depth of about 12 inches. Furrows were made 5 feet apart, to accommodate four rows of cane in each plot. The field

TABLE 1.-Treatment differentials established on the experimental field on a heavy claypan soil in east-central Puerto Rico, showing other treatments occurring in the same group according to design used

\begin{tabular}{|c|c|c|}
\hline Treatment No. & Description & $\begin{array}{l}\text { Other treatments in } \\
\text { the same group }\end{array}$ \\
\hline $\begin{array}{l}1 \\
2 \\
3 \\
4 \\
5 \\
6 \\
7 \\
8 \\
8\end{array}$ & $\begin{array}{l}\text { Check } \\
\text { Subsoiling } \\
\text { Subsoiling }+ \text { fertilizer on subsoil } \\
\text { Subsoiling }+ \text { lime on subsoil } \\
\text { Subsoiling }+ \text { fertilizer and lime on subsoil } \\
\text { Subsoiling and mole drainage } \\
\text { Subsoiling and mole drainage + fertilizer on } \\
\quad \text { subsoil } \\
\text { Subsoiling and mole drainage }+ \text { lime on sub- } \\
\quad \text { soil } \\
\text { Subsoiling and mole drainage + lime and ferti- } \\
\text { lizer on subsoil }\end{array}$ & $\begin{array}{l}2,3,4,5,7,9 \\
1,3,5,6,7,8 \\
1,2,4,6,8,9 \\
1,3,5,6,7,8 \\
1,2,4,6,8,9 \\
2,3,4,5,7,9 \\
1,2,4,6,8,9 \\
2,3,4,5,7,9 \\
1,3,5,6,7,8\end{array}$ \\
\hline
\end{tabular}

${ }^{1}$ Refer to table 3 for the grouping system.

was then ready for establishing the treatment differentials and planting, but these operations were deferred to a later date because of the unusually heavy rains during the latter part of November and early December. About the middle of January, after a few days of sunlight and no rain, a fourth disking was made to eliminate weed growth, and the furrows were opened again. Surface drainage was provided by open ditches placed at right angles to the furrows every 25 feet. These cross ditches led to larger ones which carried the water out of the field.

The treatment differentials were established during the period from January 17 to 24,1951 , as described in table 1 . In this table also are shown the other treatments which occurred in same group with each respective treatment.

For these treatments an International TD-9 diesel crawler tractor, 
wide-thread model (60-inch width center to center of tracks), with 16inch track shoes; a heavy-duty equalizer spring; and extended tracks and track frames, was used. A hydraulic system consisting of pump, valve, tank, and hoses, to operate an International-Universal tool-bar (basic) was directly connected to the tractor. The tool-bar floated and was hinged for horizontal movement. On this bar was mounted a heavy-duty standard with a subsoil point and a removable mole attached. A fertilizer attachment for subsoil was mounted so as to be motivated by the tractor's power take-off which stopped automatically when the tool-bar was in the raised position for turning and transporting the tractor, and started automatically when the tool-bar was lowered. The standard was so graduated that the subsoil point would penetrate 30 inches.

In treatments $3,5,7$, and 9 , a 13-3-12 fertilizer was applied to the subsoil at the rate of 1,000 pounds to the acre. In treatments $4,5,8$, and 9 , an application of limestone at the rate of 1,000 pounds to the acre was made at the subsoil break-point, as lime-requirement tests indicated (16). Each treatment was replicated nine times. Cane variety P.O.J. 2878, standard for the region, was planted in the period from February 7 to 21. Each plot had four rows of cane 5 feet apart. Two applications of fertilizer 13-312 were made later to a total of 2,000 pounds to the acre. The first and second surface applications of fertilizer were at only half the rate for plots fertilized at the subsoil as for those that had not previously received this subsoil treatment. Other agronomic practices were conducted as was customary for the region.

The plant crop was harvested during the period from April 21 to 26, 1952. The cane of each plot was weighed in the field and samples of 20 canes each were taken at random from each plot. They were milled at the Station and the juice samples analyzed for Brix and polarization. The yield of available $96^{\circ}$ sugar percent cane was calculated from that data and the weight of the sample and the juice obtained.

\section{RESULTS AND DISCUSSION}

The results of the statistical study of the data on sugar yields of the plant crop are presented in tables 2 and 3 . Table 2 shows the analysis of the total sum of squared deviations of the data. The values for $B$ and $E$ are 144.20 and 49.24 , respectively. These values are further used in correcting the mean yields obtained. Table 3 gives the corrected mean sugar yields for each tillage treatment. The form of presentation facilitates comparison between treatments to detect their significance.

The mean sugar yield of the check plots was 91.5 hundredweights to the acre. The mean sugar yield of all plots, including checks, (treatments 1, 2, 4,6 , and 8) which received all the fertilizer on top of the soil, as is customary 
in sugarcane fields, was only 92.4, whether sufficient lime was added to satisfy the lime requirement of the subsoil or not. A mean sugar yield of 106.8 hundredweights to the acre was obtained from all plots (treatments $3,5,7$, and 9 ) where half of the fertilizer was applied at the subsoil break-

TABLE 2.-Analysis of total sum of squared deviations of sugar yield data obtained from tillage experimental field in east-central Puerto Rico

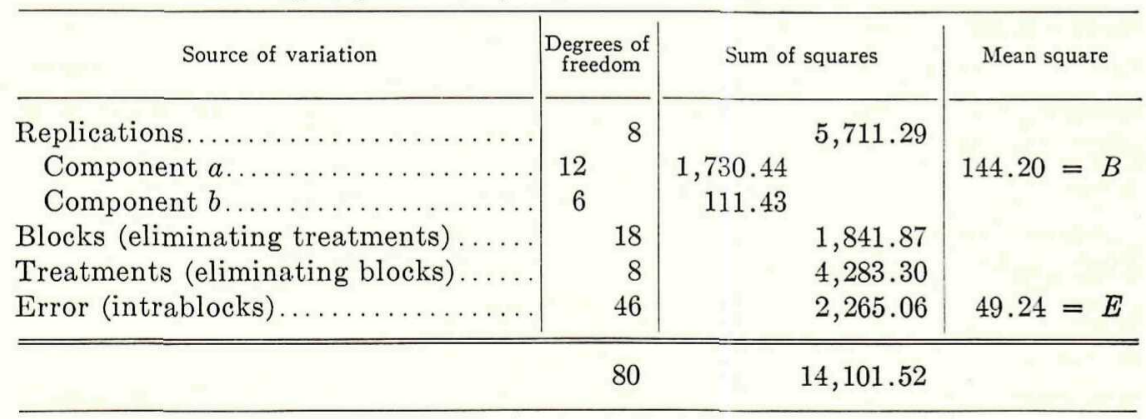

TABLE 3.-Corrected mean sugar yields for each treatment in tillage experimental field in east-central Puerto Rico ${ }^{1}$

\begin{tabular}{lccc}
\hline Treatment & $1(a)$ & $2(b)$ & $3(c)$ \\
Cwts. of sugar per acre & 91.5 & 91.0 & 104.7 \\
& & & \\
Treatment & $4(c)$ & $5(a)$ & $6(b)$ \\
Cwts. of sugar per acre & 95.4 & 104.9 & 91.5 \\
& & & \\
Treatment & $7(b)$ & $8(c)$ & $9(a)$ \\
Cwts. of sugar per acre & 108.3 & 94.4 & 109.1
\end{tabular}

${ }^{1}$ Lower-case letters in parenthesis refer to $Z$ grouping in the statistical analyses. For other treatments within the same group see table 1 .

L.S.D. for treatments within the same group:

$\begin{array}{ll}\text { at the 5-percent level } & 7.26 \\ \text { at the 1-percent level } & 9.70\end{array}$

L.S.D. for treatments not within the same group:

$\begin{array}{lr}\text { at the } 5 \text {-percent level } & 7.77 \\ \text { at the 1-percent level } & 10.76\end{array}$

point and half on the surface soil, whether lime was applied at the subsoil or not. The mean sugar yield of all plots receiving fertilizer in the subsoil was significantly higher than that from the plots where all the fertilizer was applied to the topsoil.

As previously pointed out, the common practice in sugarcane fields is to place the fertilizer on top of the soil surface. This practice probably encourages the development of rather shallow root systems. Yields depend 
upon the volume of soil, as well as upon that portion of its nutrient content that crop plants can exploit. It is a common belief that the sugarcane plants are shallow-rooted. Lee, in his studies on the root distribution of sugarcane in Hawaii observed that more than 90 percent of the roots were found in the topmost 16 inches of soil (7).

Veihmeyer and Hendrickson have shown that one of the controlling factors in root penetration is soil density (24). There is a distinct possibility that a deeper root system can be developed by cane plants in compact soils if both the physical and chemical properties of the subsoils are im-

TABLE 4.-Mean $p H$, organic matter, nitrogen, total exchange capacity, and exchangeable bases of soil where tillage experiment is located

\begin{tabular}{|c|c|c|c|c|}
\hline \multirow{2}{*}{ Factor } & \multicolumn{4}{|c|}{ Values at soil depths of- } \\
\hline & $0-7^{\prime \prime}$ & $7-16^{\prime \prime}$ & $16-26^{\prime \prime}$ & $26^{\prime \prime}$ \\
\hline $\mathrm{pH} \ldots \ldots \ldots \ldots \ldots \ldots$ & 6.6 & 6.0 & 4.9 & 5.0 \\
\hline Organic matter (percent)....... & 1.0 & (1) & (1) & (1) \\
\hline Nitrogen (percent)........... & .15 & .02 & .02 & (1) \\
\hline $\begin{array}{l}\text { Total exchange capacity (m.e./ } \\
100 \mathrm{gm} . \text { dry soil).............. }\end{array}$ & 9.5 & 10.0 & 11.4 & 12.5 \\
\hline $\begin{array}{c}\text { Total bases (m.e./100 gm. dry } \\
\text { soil) } \ldots \ldots \ldots \ldots \ldots \ldots \ldots \ldots\end{array}$ & 8.3 & 7.8 & 5.4 & 4.3 \\
\hline $\begin{array}{l}\text { Calcium (m.e./100 gm. dry } \\
\text { soil } \ldots \ldots \ldots \ldots \ldots \ldots \ldots \ldots \ldots \ldots\end{array}$ & 7.6 & 7.3 & 4.5 & 2.5 \\
\hline $\begin{array}{l}\text { Magnesium (m.e./100 gm. dry } \\
\text { soil) } \ldots \ldots \ldots \ldots \ldots \ldots \ldots \ldots\end{array}$ & .6 &.$\tilde{0}$ & .8 & 1.6 \\
\hline $\begin{array}{r}\text { Manganese (m.e./100 gm. dry } \\
\text { soil) } \ldots \ldots \ldots \ldots \ldots \ldots \ldots\end{array}$ & .005 & .01 & .05 & .06 \\
\hline Potassium . . . . . . . . . . & (1) & (1) & (1) & $(1)$ \\
\hline
\end{tabular}

1 Trace.

proved. Furthermore, in soils with subsoils in favorable physical condition, the addition of plant nutrients will also promote better root development. If the conditions that influence root extension are favorable both from the standpoint of tilth and nutrient availability, better crop yields are likely to be obtained.

Table 4 shows the fertility status of the soil where the experiment was carried out. This soil was slightly acid at the surface and acid in the subsoil, and rather low in fertility. It was not well supplied with organic matter, nitrogen, potassium, and calcium. Except for the exchangeable calcium, which decreased from 7.6 m.e. in the surface soil to 2.5 m.e. in the lower layer, there were no important differences in the fertility status of surface soil and subsoil. The total exchange capacity was moderate through- 
out the profile. It is of importance to fertilize this soil adequately if profitable crop yields are to be obtained.

In the area where this experiment was carried on, as well as in Puerto Rico as a whole, sugarcane is generally fertilized quite heavily. The mean yields of sugar obtained from the plant crop herein reported emphasize the necessity for adequately fertilizing both soils and subsoils. A mean significant difference of more than 14 hundredweights of sugar was obtained when the fertilizer application was split equally between soil and subsoil. This is an increase of 16 percent on a basis of the yields of the plots where all the fertilizer was applied on the surface. There were no significant differences between the mean sucrose contents of the cane harvested from plots where the fertilizer was placed at the top and those where it was split equally between soil and subsoil.

The differences in sugar yields were attributable to increased cane tonnage produced by subsoil fertilization. At current prices in the world market 14 hundredweights of sugar have a value of approximately $\$ 85$. Since nearly two-thirds of this value goes to the grower, after deducting milling expenses, a gross income of $\$ 56$ can be obtained. Even when due allowance is made for the increased power and labor that subsoil fertilization demands, and the increased harvesting and hauling costs involved for the extra tonnage, the sugarcane grower will obtain a larger net profit when fertilizing the subsoil and the topsoil both than when fertilizing only the latter.

The residual effect of the original subsoil fertilization remains to be determined in succeeding ratoon crops. It might prove advantageous to fertilize the subsoil yearly. Additional information is needed from other soil areas. Meanwhile the result available provide a rather important reference point as to what to expect from subsoiling and subsoil fertilization in sugarcane-producing areas.

\section{SUMMARY}

Data are presented here on sugar yields obtained from a heavy claypan soil under different tillage treatments. The mean sugar yield of all plots, including checks, which were fertilized only on the topsoil, was 92.4 hundredweights to the acre, whether sufficient lime was added to satisfy the lime requirement of the subsoil or not. The mean sugar yield of all plots which received half of the fertilizer in the subsoil and half in the surface soil was 106.8 hundredweights to the acre, whether lime was present or absent in the subsoil. The mean differences were significant. It seems that when the conditions that influence root extension are favorable both from the standpoint of tilth and nutrient availability, better crop yields are likely to be obtained, and fertilization of the subsoil fosters such condition. 


\section{RESUMEN}

Se presentan aquí datos sobre la producción de azúcar en un suelo pesado con un "claypan" sometido a varios tratamientos durante las operaciones de preparación del terreno y cultivo. La producción media de azúcar en las parcelas, incluyendo los testigos, donde todo el abono se aplicó en la superficie del suelo, como se acostumbra corrientemente en el cultivo de caña, fué de 92.4 quintales por acre; lo mismo en presencia que en ausencia de cal en el subsuelo. La producción media de las parcelas, donde la mitad del abono se aplicó en el subsuelo y la otra mitad en la superficie, fué de 106.8 quintales por acre, tanto en ausencia como en presencia de cal. Las diferencias medias son significativas. Es de esperarse, que cuando las condiciones que afectan el desarrollo de las raíces sean favorables, tanto desde el punto de vista de las propiedades físicas, como de las propiedades químicas del suelo, se obtengan mejores rendimientos.

\section{LITERATURE CITED}

1. Borden, R. J., Are there possibilities on subsoil fertilization?, Gilmore Hawaii Sugar Manual, pp. 19-25, 1947-48.

2. Brasher, E. P., Effect of plowing and discing soils on the yield of tomatoes, muskmelons and potatoes, Amer. Soc. Hort. Sci. Proc. (1948) 51 357-8 1949.

3. Chilcott, E. C. and Cole, J. S., Subsoiling, deep tilling and dynamiting in the Great Plains, J. Agr. Res. 14 481-521 1918.

4. Cox, G. M., Eckhardt, R. C. and Cochran, W. G., The analysis of lattice and triple lattice experiments in corn varietal tests, Res. Bul. 281, 66 pp., Iowa State Coll. of Agr., Agr. Expt. Sta., September 1940.

5. Jones, G. D., Method and effect of deep tillage, Agr. Eng. 20 61-3 1939.

6. Kelley, O. J., Hardman, J. A. and Jennings, D. J., A soil sampling machine for obtaining two-, three-, and four-inch diameter cores of undisturbed soil to a depth of six feet, Soil Sci. Soc. Amer. Proc. 12 85-7 1948.

7. Lee, H. A., The distribution of the roots of the sugarcane in the soil of the Hawaii Islands, Plant Physiol. 13631926.

8. Lill, J. G., Plowing depths and fertilizers affect sugar beet crop, Mich. Agr. Expt. Sta. Quart. Bul. 13 122-127 1931.

9. Martínez, M. B. and Lugo-López, M. A., Plans for research on the effect of subsoiling and subsoil fertilization on sugar cane fields, Sugar J. 14 36-43 1951.

10. Martínez, M. B. and Lugo-López, M. A., Tillage tests: I, Effect of subsoiling and mole drainage upon the minimum infiltration capacity of a heavy claypan soil of the Tropics, J. Agr. Univ. P. R. 36(2) 179-85 1952.

11. Mosier, J. G. and Gustafson, A. F., Soil moisture and tillage for corn, Ill. Agr. Expt. Sta. Bul. 181 563-86 1915.

12. Nissley, C. H., Our forgotten soil, Country Gent.110(2) 151940.

13. Osborn, W. M., Rotation and tillage experiments at the Lawton (Okla.) Field Station, 1917-1930, U. S. Dept. Agr. Tech. Bul. 3301932.

14. Peech, M., Determination of exchangeable bases in soils, Ind. Eng. Chem. 13436 1941.

15. Randolph, J. W., Reed, I. F. and Gordon, E. D., Cotton-tillage studies on Red Bay sandy loam, U. S. Dept. Agr. Cir. 5401940. 
16. Riera, A., Laboratory recommendations of lime to an acid soil checks with expected $\mathrm{pH}$ changes, J. Agr. Univ. P. R. 30(3) 184-185 1946.

17. Roberts, R. C., Soil Survey of Puerto Rico, U.S.D.A. Series 1936 (9) Bur. of Plant Industry in cooperation with Univ. of P. R. Agr. Expt. Sta. 503 pp., 1942.

18. Russell, E. W. and Keen, B. A., Studies in soil cultivation: VII, J. Agr. Sci. 28 212-33 1938.

19. Russell, E. W. and Mehta, N. P., Studies in soil cultivation: VIII, J. Agr. Sci. 28 272-98 1938.

20. Russell, E. W. and Keen, B. A., Studies in soil cultivation: X, J. Agr. Sci. 31 326-47 1941.

21. Sarvis, J. T. and Thysell, J. C., Crop rotation and tillage experiments at Northern Great Plains Field Station, Mandan, N. Dak., U. S. Dept. Agr. Tech. Bul. 5361936.

22. Smith, D. D., Woodruff, C. M. and Whitt, D. M., Building a soil deeper, Agric. Eng. 28 347-8 1947.

23. Smith, R. S., Experiments with subsoiling, deep tilling and subsoil dynamiting, Ill. Agr. Expt. Sta. Bul. 2581925.

24. Veihmeyer, F. J. and Hendrickson, A. H., Soil density and root penetration, Soil Sci. 65 478-93 1948.

25. Wolters, W., Root distribution, Reports Assn. Hawaiian Sugar Tech. pp. 71-80, 1928.

26. Woodruff, C. M. and Smith, D. D., Subsoil shattering and subsoil liming for crop production on claypan soils, Soil Sc. Soc. Amer. Proc. 11 539-42 1946. 